\title{
A INDUMENTÁRIA DA MARUJA COMO “TELA DE REPRESENTAÇÃO” NA DEVOÇÃO BENEDITINA EM BRAGANÇA-PA
}

\author{
Ana Mabell Seixas Alves Santos ${ }^{1}$ \\ Luis Junior Costa Saraiva ${ }^{2}$
}

\begin{abstract}
RESUMO
Este artigo é parte de uma pesquisa desenvolvida para uma Dissertação de Mestrado no Programa de Pós-Graduação em Linguagens e Saberes na Amazônia (PPLSA-UFPA), e tem por tema uma contextualização do conceito de "tela de representação" proposto por Hall (2003). Este conceito trata da utilização, pela cultura negra, do corpo como capital cultural devido à impossibilidade de outros recursos expressivos no sistema escravista e na dominação eurocêntrica durante a diáspora. Compreendemos a figura da maruja em Bragança-PA, que resulta de uma devoção fundada na cidade por negros escravizados no final do século XVIII e marcada por tensões de poder, como uma tela de representação. Deste modo, a indumentária da maruja articula repertórios africanos com elementos do catolicismo, comunica identidades, corporifica a fé em São Benedito e delimita espaços no contexto da festividade do santo preto.
\end{abstract}

Palavras-chave: Telas de Representação. Indumentária. Marujada.

\begin{abstract}
This article is part of a research developed for a Master's degree dissertation in the Linguagens e Saberes na Amazônia Post-Graduation Program (PPLSA-UFPA), and it has as its theme a contextualization of the concept of "canvas of representation" proposed by Hall (2003). This concept crosses the use, by the black culture, of the body as a cultural capital due to the impossibility of other expressive resources in the slavery system and in the Eurocentric domination during the diaspora. We understand the figure of the maruja in Bragança-PA, which results from a devotion founded in the city by black enslaved people in the end of the XVIII century and marked by power tensions, as a canvas of representation. Thus, the maruja attire articulates African repertoires with Catholic elements, communicates identities, embodies the faith in Saint Benedict and delimits spaces on the context of the Black Saint festivity.
\end{abstract}

Keywords: Canvases of Representation. Attire. Marujada.

Recebido em: 09/05/2017

Aprovado em 14/06/2017

\section{REPERTÓRIOS EM DESLOCAMENTO.}

Aquilo a que se convencionou chamar "cultura popular", encobre, sob a expressão no singular, diferenças e contradições que negam concepções homogeneizantes. No contexto da marujada de São Benedito de Bragança-PA, manifestação religiosa historicamente associada

\footnotetext{
1 Mestre em Linguagens e Saberes na Amazônia pela Universidade Federal do Pará (UFPA), belseixas@yahoo.com.br.

${ }^{2}$ Doutor em Antropologia. Professor do Programa de Pós-Graduação Linguagens e Saberes na AmazôniaUFPA/Campus- Bragança (PPLSA), luisjsaraiva@gmail.com.
} 
às classes subalternas da cidade por sua origem durante a vigência do sistema escravista, o discurso dos sujeitos quanto ao que seria a "tradição" está invariavelmente relacionado à materialidade que compõem sua estética: o andor do santo, as bandeiras, estandartes e a indumentária das marujas, as mulheres beneditinas que são as protagonistas da festividade (NONATO DA SILVA, 2006). O "popular", neste caso, ao mesmo tempo em que legitima a manifestação como autêntica, serve como palco para a dominação ideológica e econômica, pois,

O papel do "popular" na cultura popular e o de fixar a autenticidade das formas populares, enraizando-as nas experiências das comunidades populares das quais elas retiram o seu vigor e nos permitindo vê-las como expressão de uma vida social subalterna especifica, que resiste a ser constantemente reformulada enquanto baixa e periférica. Entretanto, como a cultura popular tem se tornado historicamente a forma dominante da cultura global, ela é, então, simultaneamente, a cena, por excelência, da mercantilização, das industrias onde a cultura penetra diretamente nos circuitos de uma tecnologia dominante — os circuitos do poder e do capital. (HALL, 2003, p.341)

A indumentária da maruja é frequentemente retratada em fotografias, pinturas em telas e muros, graffiti e mesmo em souvenirs oferecidos a turistas na cidade, sempre obedecendo a um padrão considerado genuinamente "popular" e "tradicional", mas cujos elementos não são considerados isoladamente, de modo a perscrutar suas possibilidades simbólicas. Ou, dito de outra forma, à figura da maruja no presente é atribuída a semelhança com o passado, de modo a minimizar transformações e assimilações, ainda que, tal como observado por Hall (2003), exista a penetração de circuitos de poder e do capital.

. Em pesquisas acadêmicas, a exemplo desta de Moraes, Aliverti e Silva (2006), os adereços coloridos das marujas recebem especial atenção:

No dia 25 de dezembro, Dia da Natividade, as marujas se vestem com saias longas, compridas até atingir o tornozelo, rodadas nas cores azul-claro ou azul-turquesa. Algumas escolhem um tecido rendado, outras, brilhoso; não há uniformidade quanto ao padrão do tecido, o que importa é a cor. A blusa é branca, geralmente bordada ou rendada, com mangas curtas e o corpete solto abaixo da cintura.

O chapéu é o item mais pomposo que compõe o figurino, e sua feitura envolve um longo processo artesanal. [...] Para sua confecção, um dos materiais principais são as penas de pato. [...] As penas são arranjadas de modo a formar pequenas flores brancas, que são presas por botões a uma armação que pode ser de palha, haste metálica, ou de isopor, esta torna o chapéu mais leve. A armação é recoberta por tecido, aumentando a altura da copa, enquanto a aba é recortada com tecido ou papel dourado.

Completando sua ornamentação, amarra-se uma série de fitas de cetim das mais diversas cores, de um metro de comprimento que, durante os giros das marujas, parecem um arco-íris.

Entre os adereços há uma rosa azul colocada ao lado esquerdo, acima do peito, uma faixa azul transpassada em volta da blusa e, completando o visual, muitos colares e pulseiras. [...]

Os pés descalços simbolizam a humildade contrastada com o uso de maquiagem no 
rosto e o caminhar e dançar com graça e altivez ${ }^{3}$.

No dia 26 de dezembro repetem o mesmo padrão de vestimentas e ornamentos, havendo mudança para as cores vermelho e branco. (MORAES, ALIVERTI; SILVA, 2006, p.69) ${ }^{4}$

A descrição dos autores, embora detalhada, ilustra a escassez de fontes sobre as razões pelas quais a indumentária da maruja assumiu a forma como a conhecemos hoje. Além dos pés descalços, que aludem à humildade, pouco ou nada é dito a respeito do que representariam as demais peças e acessórios. Esta escassez, como aponta Alencar (2014), sugere um silenciamento das origens africanas. No mesmo sentido, Fernandes (2011), aponta uma negação da aproximação com religiões de matriz africana em função de um discurso favorável ao controle eclesiástico. Os repertórios da cultura popular negra, assim referidos por Hall (2003), neste caso, foram deslocados a uma percepção periférica ou marginal que admite como herança africana apenas o referencial étnico de São Benedito, o Santo Preto, a quem os escravizados que fundaram a Irmandade do Glorioso São Benedito (IGSBB) rendiam suas homenagens.

\section{BENEDITO SOB “OLHOS SEVEROS”.}

Há alguns pontos essenciais que permeiam a identificação dos negros escravizados que iniciaram a devoção beneditina em Bragança com o santo a quem prestavam suas homenagens. O primeiro deles deriva da origem africana comum entre São Benedito e estes devotos, pois “a família de Benedito era descendente da África. Oriundos da Etiópia, os avós do Santo eram tipos legítimos do africano daquela região. Benedito nasceu com aquela cor dos nascidos na África". (BRANDÃO, 1979, p. 9). Mas havia, além daquela "cor dos nascidos na África", outras semelhanças em fatos narrados no que se conhece como a biografia do santo:

São Benedito foi um dos primeiros santos negros a ser efetivamente canonizado pela cúria romana, em 1763. Nasceu na Sicília, Itália, em 1526. Seus pais eram descendentes de escravos vindos da Etiópia, mais tarde libertos por seus senhores. Sua família era pobre e o Mouro, como era chamado, foi pastor de ovelhas e

\footnotetext{
${ }^{3}$ O mesmo vestuário utilizado pelas marujas no dia 25 de dezembro, embora não mencionado pelos autores, é também ostentado na abertura da festividade de São Benedito, dia 18 de dezembro, na chamada "alvorada".

${ }^{4}$ Sobre a vestimenta dos marujos, segundo Brandão da Silva (1997): "O uniforme masculino constitui-se de calça comprida e camisa de mangas compridas, um chapéu de palha forrado em tecido branco, com uma fita vermelha ou azul, e um laço pregado". O autor não menciona, contudo, a rosa azul ou vermelha que, conforme o dia - respectivamente, 18 e 25 ou 26 de dezembro - orna o lado direito da aba do chapéu masculino e as fitas que os marujos levam ao braço esquerdo e que seguem o mesmo padrão de cores; tampouco menciona que, no dia 25, camisas azuis acompanham as calças brancas, enquanto no dia 26 o uniforme é inteiramente branco, exceto pelas fitas e rosas vermelhas.
} 
lavrador. Aos 21 anos foi chamado por um monge para viver entre os Irmãos Eremitas de São Francisco de Assis. Depois de 17 anos, transferir-se para o Convento dos Capuchinhos, onde foi designado para ser o cozinheiro do convento, permanecendo nesse serviço até quando foi eleito pelos seus irmãos de comunidade como superior do Mosteiro. (VAT, 1941, p.60)

Benedito, negro, filho de escravizados, nascido em outro país que não o de seus pais, franciscano, pastor de ovelhas, lavrador e cozinheiro - atividades historicamente exercidas por classes menos favorecidas - e que, apesar de todas as circunstâncias que lhe eram desfavoráveis, teve seu reconhecimento nos céus, pode ser compreendido como exemplo de um santo acessível, próximo, quase palpável. Isto explicaria a grande aceitação do culto a Benedito em Bragança em muitas regiões do Brasil, antes mesmo de sua canonização. A devoção

Iniciou-se na Bahia. Na catedral da Bahia, em 1686, já se festejava o Beato e, neste mesmo ano, foram criados e encaminhados a Roma os estatutos da Irmandade do Bem Aventurado Frei Benedito de Palermo. Antes da canonização o Santo já estava sendo popular no Brasil. (BRANDÃO, 1979, p.105-106)

A devoção, à época, acontecia à margem do catolicismo oficial. Sua autorização, por parte da Igreja, ocorreu apenas em 1743, e a canonização mais de meio século depois, no ano de 1807 (FERRETI, 1998). No Pará, “entre as devoções populares que o negro assimilou do catolicismo a mais disseminada é, sem dúvida, a de São Benedito, patrono de muitas freguesias, cujas irmandades se multiplicaram por todo o Estado" (SALLES, 2015, p.34).

A Irmandade do Glorioso São Benedito de Bragança (IGSBB) foi fundada em 1798 antes, portanto, da canonização de Benedito - com o caráter de instituição religiosa. A devoção, porém, provavelmente já existia antes desta fundação. Sobre este ponto, Fernandes (2011) afirma que

É quase certo que, ao instituir-se uma manifestação, do ponto de vista legal, o que se fez foi a ratificação de um direito consuetudinário, pois a Irmandade foi a legalização de prováveis manifestações de caráter profano dos negros escravizados. (p.57-58)

Brandão da Silva (1997) aponta que a IGSBB não foi criada pelos segmentos desfavorecidos da sociedade bragantina, mas que surgiu como uma concessão das elites brancas que, articuladas com o poder eclesiástico, procuraram massificar o cristianismo e legitimar o sistema escravocrata, evitando conflitos, fugas e rebeliões. Isto porque "as possibilidades de reorganização sócio-espacial e de inserção do negro no sistema colonial escravista foram limitadas a um elemento dentro do sistema institucional: as irmandades leigas destinadas a negros e gentios" (Lima Ivo, 2006, p.38). De fato, havia um referencial 
étnico no Compromisso datado de 1853, que determinava que a Irmandade seria composta por “pardos e pretos de ambos os sexos" (Brandão da Silva, 1997, p.26)

Desde então, a história da IGSBB foi marcada pela dominação, havendo apenas a transição do sistema escravocrata para o sistema burguês, validada por meio do estatuto de 1947, quando a irmandade deixou de ter caráter religioso para ser transformada em irmandade civil. O documento marcou também a inserção de brancos em seu quadro e o reconhecimento da marujada - até então considerada uma manifestação marginal - como parte oficial da "festa do santo".

O deslocamento da marujada da margem para o centro da festividade e a reconfiguração da IGSBB em uma sociedade civil poderiam sugerir, à primeira vista, uma forma menos rigorosa para que negros e mestiços pudessem exercer suas práticas de culto. No entanto, com o mesmo estatuto de 1947 o requisito para ingresso na IGSBB foi substituído de "pretos ou pardos de ambos os sexos" para "brasileiros de ambos os sexos, de qualquer idade ou profissão, católico [...]” (BRANDÃO DA SILVA, 1997, p.56). Com isso, a imposição do critério do catolicismo afastava intencionalmente quaisquer outras formas de devoção no contexto da marujada.

Isto porque a marujada somente poderia ser vinculada a um ritual religioso se fosse implementada pelo clero, não por leigos, em culto profano, numa nítida disputa de quem poderia ou não ser responsável pelos rituais e práticas religiosas. (FERNANDES, 2011, p.60)

Esta configuração perdurou até 1988, quando, após uma longa disputa judicial, a Igreja retomou o controle da festividade e a IGSBB foi extinta. Nos dias correntes, é a Irmandade da Marujada de São Benedito de Bragança (IMSBB), criada em 1985, que conduz as apresentações da marujada (FERNANDES, 2011, p.63). A procissão de São Benedito, da qual participam marujos, marujas e demais devotos, é organizada pelo poder eclesiástico do município.

A devoção, portanto, esteve historicamente marcada por uma dominação ideológica que estabelecia as formas pelas quais a fé deveria ser manifestada. Estas relações assimétricas levam ao que entendemos como outro pilar da identificação dos devotos com São Benedito, além do referencial étnico e social: ao santo é atribuída uma personalidade humilde como convém aos franciscanos, mas na qual um senso de justiça pessoal se sobrepõe às normas da hierarquia católica. Tal atribuição pode ser claramente percebida na narrativa de um milagre

\footnotetext{
${ }^{5}$ Brandão da Silva (1997) pontua que a existência de Irmandades compostas apenas por negros era comum em algumas regiões brasileiras, sendo a participação de brancos restrita aos cargos de secretário e tesoureiro, e ainda assim somente em caso de ausência de negros e pardos alfabetizados para que ocupassem tais cargos.
} 
operado pelo santo ainda em vida, o chamado "milagre das rosas":

Sempre que podia, Benedito apanhava alguns alimentos de sua cozinha, metia-os nas dobras do burel e, disfarçadamente, os levava aos necessitados. Conta-se que numa dessas ocasiões, o santo foi surpreendido pelo superior do convento, que perguntou: "Que levas aí, na dobra do teu manto, irmão Benedito?" E o santo respondeu: "Rosas, meu senhor!". São Benedito desdobrou o burel franciscano e, em lugar dos alimentos suspeitados, apresentou aos olhos severos do superior uma braçada de rosas. (VAT, 1941, p.61)

Por esta narrativa, bastante conhecida entre os devotos do santo, pode-se suscitar duas características de Benedito que servem à compreensão das tensões da marujada: a primeira constitui a irrestrita bondade para com os mais pobres; a segunda, derivada daquela, representa uma inclinação ao descumprimento das regras estabelecidas em situações nas quais estas contrariassem sua consciência. Neste caso, o próprio Deus teria dado razão a Benedito, uma vez que a desobediência se justificaria pela caridade: há, na transformação dos alimentos em rosas, um sinal divino de que ele não mereceria uma advertência ou punição por parte do superior que o proibia de distribuí-los. Pela lógica devota, a igreja pode cometer erros, mas Benedito não, e Deus sabe disso. São Benedito seria, por esta mesma lógica, humano na transgressão e na dissimulação, mas divino nas intenções que as justificam.

Esta intepretação o aproxima do indivíduo de carne e osso que o toma como parte de sua realidade. Por isso, para um devoto, "o seu Santo de devoção não é visto como algo impessoal e longínquo, mas ao contrário, como uma entidade que pertence ao seu mundo social” (BRANDÃO DA SILVA, 1997, p.266).

Este pertencimento representa um processo semelhante àquele em que "o vínculo entre o santo e o devoto estabelece progressivamente uma relação de compromisso, onde deveres e direitos vão se explicitando, na forma de normas de conduta, rituais e castigos impostos a ambos os lados" (LOPES, 2010, p.128). Digo que o processo é "semelhante" e não idêntico ao descrito por Lopes (2010) porque não houve, em minhas conversas com as artesãs marujas, quaisquer menções a histórias nas quais São Benedito tenha sido posto "de castigo" como nas práticas populares em que imagens de Santo Antônio são escondidas ou postas de cabeça para baixo quando este não cumpre a função de casamenteiro.

Em lugar dos castigos infligidos a ambos os lados, as devotas com as quais conversei relatam castigos apenas ao devoto que "desrespeitar" o santo. Isto porque "São Benedito é outro santo considerado muito milagroso - e também muito 'perigoso', com quem não se pode brincar” (MAUÉS, 2005, p.26). O vínculo entre o devoto e Benedito é marcado pelo compromisso e pela proximidade, tal como pontuado por Lopes (2010), e pelo grande poder 
do santo em operar milagres, tal como observado por Maués (2005), porém apenas o devoto presta obediência. No mesmo sentido,

Outro santo católico cujo culto é muito difundido no Brasil é São Benedito. No
Maranhão, como em diversas outras regiões, São Benedito é considerado padroeiro
e protetor dos negros. E visto popularmente como um santo esperto e mesmo
vingativo, mas que protege seus devotos, sejam eles ricos ou pobres. (FERRETTI,
1998, p.191)

Em Bragança, especialmente na esmolação, há uma relação anímica estabelecida pelos devotos em relação a São Benedito. Esta relação é observada por Fernandes (2011, p.86), segundo o qual “a animização do santo não é apenas para o 'bem', quando atende aos pedidos dos devotos. Também é o santo que 'castiga', apresentando 'atitudes' que revelam sua insatisfação ou aprovação [..]". Nesta relação, o santo seria uma entidade que repreende para ensinar por "exemplos".

De toda forma, seja a interpretação popular a de um santo "perigoso", tal como descrito por Maués (2005), ou de "esperto" e "vingativo", como registrado por Ferretti (1998), ou simplesmente a de uma entidade que castiga para dar "exemplo", como analisado por Fernandes (2011), em todos os casos há algum grau de deslocamento da placidez com que são descritos outros santos católicos em direção à fluidez das divindades africanas. É possível compará-lo aos orixás, cujos humores são mutáveis como os elementos da natureza que regem. Cascudo (1962) aponta a inexistência de registros em que São Benedito tenha sido sincretizado com algum orixá ${ }^{6}$ e sugere que isto se deve ao fato de o santo ser negro, o que geraria uma identificação étnica que afastaria a necessidade de outras associações ${ }^{7}$.

Esta perspectiva híbrida sobre o "santo preto" existe também na marujada, refletindo a tensão entre "catolicismo popular" e "catolicismo oficial" identificada por Brandão da Silva (1997, p.54). Diante das divergências entre as nuances anímicas atribuídas ao santo e o poder eclesiástico no município, pode-se dizer que, tal como na narrativa de Vat (1941) sobre o controle do superior do convento e o "milagre das rosas", também em Bragança Benedito sempre esteve sob "olhos severos".

\footnotetext{
${ }^{6}$ A afirmação de Cascudo (1962) se refere aos estados da Bahia e do Rio de Janeiro.

${ }^{7}$ Há registros de sincretismo em outros estados: "São Benedito, sincretizado com Verequete, é considerado guia ou chefe dos terreiros de tambor de mina do Maranhão" (FERRETTI, 1998).
} 


\section{TEMPO DILATADO, TELAS COMPRIMIDAS.}

A dualidade, ao que parece, esteve presente desde sempre na marujada. Posta à margem e ao centro, imaterial e manifesta, disputada e romantizada, romanizada e africana, senhorial e cativa, contestadora e legitimadora ${ }^{8}$. Ou ainda "laica e religiosa, profana e sagrada [...] mesmo estando às portas da Igreja enquanto instituição e espaço físico" (SANTOS; BRITO, 2016, p.37).

De fato, o estatuto da IGSBB de 1947 era evidentemente restritivo quanto à aceitação apenas de católicos entre seus membros. Ainda assim, a imposição de uma religiosidade oficial não extinguiu traços que remetem às religiões de matriz africana. Diz Fernandes (2011): "Na marujada, mesmo a despeito do reconhecimento de ser um santo preto e ter sua origem com os escravos africanos, nega-se, ou esvazia-se, em certa medida, a origem afro, particularmente com a umbanda" (p.107). É pontual a utilização, pelo autor, da expressão "em certa medida". Isto porque a relativa negação da religiosidade africana oculta seus indícios sob os ritmos, gestos, cores e, principalmente, indumentária. A similitude entre as vestes das marujas e as das mães de santo do candomblé, a presença de colares que lembram as guias africanas, a utilização de penas para esculpir o chapéu em formato de turbante (Alencar, 2014) são indícios de religiosidades sublimadas.

A diáspora impôs a diluição, reconfiguração e fusão de elementos anteriormente diversos e mesmo opostos na complexidade e especificidades do território africano (Hall, 2003), e porque havia, entre os escravizados desembarcados na região amazônica, uma diversidade étnica considerável. Isto porque a experiência da escravidão impossibilitou a manutenção de seus laços familiares e étnicos. Africanos eram trazidos às Américas em lotes cuja valoração no mercado escravista dependia, entre outros fatores, de sua variabilidade, como uma estratégia para evitar motins, fugas em massa e rebeliões. Desta maneira, tais indivíduos foram impelidos a estabelecer novas relações sociais, o que implicou igualmente no estabelecimento de novos repertórios, bem como no desenvolvimento de formas específicas de expressão de tais repertórios. Sobre este processo, cabe citar Souza (2002):

Ao serem arrancados de seus lugares de origem e escravizados, ao deixarem de pertencer a um grupo social no qual construíam suas identidades, ao viverem experiências de grande potencial traumático, tanto físico como psicológico, ao transporem a grande água e terem que se dobrar ao jugo dos senhores americanos, os africanos eram compelidos a se integrarem, de uma forma ou de outra, às terras às

\footnotetext{
${ }^{8}$ No dizer de Brandão da Silva (1997), "espaço de liberdade dentro de um sistema marcado pela dominação" (1997, p.255).
} 
quais chegavam. Novas alianças eram feitas, novas identificações eram percebidas, novas identidades eram construídas sobre bases diversas: de aproximação étnica, religiosa, da esfera do trabalho, da moradia. Assim, reagrupamentos étnicos compuseram "nações", pescadores e carregadores se organizaram em torno das atividades que exerciam, vizinhos consolidaram laços de compadrio e se juntaram cultuadores dos orixás, os que faziam oferendas aos antepassados e recebiam entidades sobrenaturais sob o toque de tambores. (SOUZA, 2002, p.128)

A autora distingue dois tipos de rearticulação religiosa: de um lado, as manifestações de matriz africana; de outro, as festas em louvor a santos padroeiros, que eram toleradas, aceitas ou mesmo estimuladas como um mecanismo de controle. Como exemplo deste primeiro tipo de rearticulação, a autora cita os cortejos de escravizados realizados entre o fim do século XIII e o início do século XIX, nos quais havia a coroação de rainhas e reis negros por padres. Tais cortejos guardam algumas semelhanças e diferenças em relação à marujada. Uma diferença reside no fato que, na marujada, não há referências diretas a autos de coroação de reis e rainhas. A maior proximidade com a realeza é representada pela capitoa, cujo bastão evidencia sua autoridade e liderança diante das outras marujas, marujos e demais participantes da festividade. Ela representa a liderança que remete ao tempo do matriarcado. "A maciça predominância feminina é uma sobrevivência do tempo da escravidão, quando a mãe respondia pela família, sem o pai levado pelo sacrifício de ser escravo". (FERNANDES, 2011, p.74). Outros elementos similares são a presença de um santo padroeiro, a organização social em torno de uma irmandade e a incorporação do rito pelo catolicismo oficial.

O segundo tipo de rearticulação religiosa corresponde a manifestações africanas demonizadas, perseguidas e proibidas pelo poder eclesiástico devido à presença de "altares que abrigavam objetos mágico-religiosos, havendo a oferenda de sangue de animais, bebida e comida, ao som de tambores e com a possessão de algumas pessoas por entidades sobrenaturais" (SOUZA, 2002, p.129). Também estas manifestações se assemelham à devoção beneditina, tanto na presença do som dos tambores que embalam o canto quanto em outros aspectos. Há um objeto mágico-religoso, representado, neste caso, pela imagem animizada de São Benedito, especialmente no contexto da esmolação; a comida, pelo almoço das marujas durante a festividade (BRANDÃO DA SILVA, 1997, p.231); a bebida, pelo arraigado costume, na parte profana da festa, do "uso da cerveja e da cachaça" (BRANDÃO DA SILVA, 1997, p.206) por parte dos marujos e marujas. Sobre os animais sacrificados, há as aves que recobrem o chapéu da maruja com suas "plumas", do qual tratarei ainda neste tópico. Finalmente, sobre o elemento da possessão, há um registro singular em uma expressão vagamente utilizada por Bordallo da Silva (1959): 
Há uma origem comum da Marujada com a Irmandade de São Benedito. Quando em 1798 , os senhores acederam ao pedido de seus escravos para a organização de uma Irmandade e foi realizada a primeira festa em louvor de São Benedito, os negros em sinal de reconhecimento, incorporados ${ }^{9}$, foram dançar de casa em casa dos seus benfeitores. (BORDALLO DA SILVA, 1959, p.62)

Em que pese a louvável preocupação do pesquisador em publicar um estudo a que chama modestamente "contribuição", o trecho demonstra a patente parcialidade - reflexo de uma concepção corrente à época - segundo o qual os senhores seriam "benfeitores" aos quais os negros deveriam "reconhecimento". A partir desta leitura, a palavra "incorporados" revela suas múltiplas interpretações. Poderia ser uma expressão que indicasse outra coisa além de incorporações espirituais; poderia indicar uma interpretação etnocêntrica de terceiros sobre religiosidade africana que, narrada ao pesquisador mais de um século e meio depois e assim cristalizada no texto; ou poderia, de fato, aludir a narrativas, entre membros da marujada, sobre incorporações por entidades, tais como as manifestações às quais Souza (2002) se referiu. De qualquer forma, tais narrativas foram paulatinamente silenciadas por uma religiosidade oficial, uma vez que estes sujeitos,

\footnotetext{
Na condição de escravos, desgarrados de seus laços familiares, pouco ou nada trouxeram de bens materiais, porém em seus corpos vieram suas memórias, a forma de sentir e dar significado à vida; no corpo trouxeram seus recortes geográficos de existência (regiões, reinados, nações, continente ou outras denominações espaciais estranhas a nós), sua cultura. (RANGEL; GOMBERG, 2016, p.4)
}

Em uma existência marcada por "recortes" dentro de um sistema de dominação material e psicológica, o único suporte disponível era o corpo, sobre o qual foram desenvolvidas linguagens distintas como a capoeira ${ }^{10}$, a musicalidade marcada pela percussão ${ }^{11}$ e a dança, que constituía "um dos meios de comunicação permitidos pelo sistema colonial” (BRANDÃO DA SILVA, 1997, p.256). De fato, Hall (2003, p. 342), ao analisar as heranças culturais africanas reconfiguradas pela diáspora, afirma que “[...] essas culturas têm usado o corpo como se ele fosse, e muitas vezes foi, o único capital cultural que tínhamos. Temos trabalhado em nós mesmos como telas de representação". A concepção do corpo como uma tela resulta da absoluta ausência de outros recursos pelos quais o sujeito negro pudesse expressar seu repertório cultural. Neste cenário, a corporalidade serviria tanto para traduzir

\footnotetext{
${ }^{9}$ Grifo nosso.

10 "O negro escravo organizou seu próprio sistema de defesa, e começou usando o próprio corpo", escreve Vicente Salles (2015, p.121).

${ }^{11}$ Hall (2003) associa esta musicalidade à tradição oral africana, salientando que "o povo da diáspora tem [...] a estrutura profunda de sua vida cultural na música" (p.342).
} 
quanto para codificar este repertório, dependendo do contexto em que o mesmo estivesse inserido. No mesmo âmbito,

Existem aqui questões profundas de transmissão e herança cultural, de relações complexas entre as origens africanas e as dispersões irreversíveis da diáspora [...] Mas acredito que esses repertórios da cultura popular negra — uma vez que fomos excluídos da corrente cultural dominante - eram frequentemente os únicos espaços performáticos que nos restavam [...] (HALL, 2009, p.343)

Pelo pensamento de Hall (2003), a exclusão do negro na cultura dominante compeliu este sujeito a nichos ou "espaços performáticos" nos quais pudesse desenvolver uma estética própria a partir de seu repertório e, simultaneamente, absorver outras influências pontuais da mesma corrente cultural que o excluía. Com isso,

\begin{abstract}
A apropriação, cooptação e rearticulação seletivas de ideologias, culturas e instituições europeias, junto a um patrimônio africano, [...] conduziram a inovações linguísticas na estilização retórica do corpo, a formas de ocupar um espaço social alheio, a expressões potencializadas, a estilos de cabelo, a posturas, gingados e maneiras de falar, bem como a meios de constituir e sustentar o companheirismo e a comunidade. (HALL, 2003, p.343)
\end{abstract}

No trecho, a "estilização retórica do corpo" ocorre de forma simultânea à ocupação de outros espaços sociais e à manutenção de laços comunitários. Entendo que estes elementos estão presentes no contexto da marujada, sendo o conceito de "tela de representação" aplicável à figura da mulher maruja. E que, no "dilatado tempo" - expressão utilizada por Bordallo da Silva $\left(1959\right.$, p.59) para aludir à longevidade da irmandade de São Benedito ${ }^{12}$ pode-se afirmar que há um processo gradual de compressão destas telas em detrimento de outras influências.

\title{
4. INDUMENTÁRIA E ESCRAVIDÃO.
}

Miller (2013), analisando a profunda relação dos cidadãos de Trinidad com seu vestuário e acessórios, aos quais dedicavam considerável tempo e recursos financeiros, chega a uma conclusão interessante. $O$ autor traça um paralelo entre esta afirmação pela indumentária, que poderia ser considerada exacerbada por outras culturas, e a experiência da escravidão. $\mathrm{O}$ autor analisa que a necessidade de manter as coisas à superfície seria uma espécie de estratégia de defesa diante da degradação extrema representada pela submissão à condição de escravizado:

\footnotetext{
${ }^{12}$ Ainda IGSBB no tempo em que o texto foi escrito.
} 


\begin{abstract}
A existência precária dada pela escravidão impedia qualquer internalização do amor, pois não havia nenhum conhecimento sobre quando este amor-objeto poderia ser tomado à força; isso resultava numa espécie de tendência adaptativa de manter as coisas à superfície, de recusar qualquer internalização e minimizar o sentimento de perda. (MILLER, 2013, p.27)
\end{abstract}

Por este prisma, a impossibilidade dos afetos suscitaria uma compensação que poderia ser obtida pela construção de uma identidade a partir de um referencial exterior. Esta tendência é comum a diferentes contextos de escravidão. No Caribe, por exemplo, "enslaved women used cloth and clothing as conduits to memorialize personal and collective histories, signify kinship, advertise status and skill, and provide material links within slave communities" (SKEEHAN, 2015, p.106). A autora observa um ponto não mencionado por Miller (2013) no trecho: além de servirem à construção das memórias destas mulheres, tecidos e roupas remetiam a memórias e comunicavam posições e relações sociais tais como o parentesco, funcionando como condutores materiais entre comunidades escravizadas.

Quanto à importância atribuída à indumentária no sistema escravista do Brasil, são particularmente interessantes dois trechos de obras de teor abolicionista que, no que pese serem absolutamente distintas em suas linguagens, permitem vislumbrar, em suas entrelinhas, questões importantes sobre o vestuário do sujeito escravizado. Ou, mais especificamente, sobre a ausência de vestuário e suas implicações na construção do sujeito. Constroem, assim, um cenário que ilustra condições extremas de vida e soam como uma fotografia em negativo da tela de representação definida por Hall (2003). Uma delas é um texto político, gênero que goza de maior familiaridade com estudos sobre a sociedade. Outro é um poema do qual, contudo, não pretendo fazer considerações literárias, e sim tecer uma pequena análise sobre a materialidade, pois "A poesia valoriza as coisas vulgares. Mesmo injustamente vulgares [...]" (CÂMARA CASCUDO, 1959, p.11). Em “O Abolicionismo"13, Joaquim Nabuco (2011) insere entre seus argumentos o trecho a seguir, segundo o qual o cativo está continuamente

[...] à mercê do temperamento e do caráter do senhor, que lhe dá de esmola a roupa e alimentação que quer, sujeito a ser dado em penhor, a ser hipotecado, a ser vendido, o escravo brasileiro literalmente falando só tem de seu uma coisa - a morte. (NABUCO, 2011, p.28)

O trecho permite uma leitura segundo a qual alimento e roupa estejam em um mesmo patamar, como necessidades primárias: o alimento concederia a sobrevivência ao corpo,

\footnotetext{
${ }^{13}$ Livro publicado por Joaquim Nabuco no ano de 1883, em Londres, no qual apresentava razões políticas, sociais e econômicas para a abolição do sistema escravista no Brasil Império, demonstrando "ao mesmo tempo identificação com o sistema oligárquico e combate a ele" (COSTA, 2003, p.82).
} 
enquanto a roupa o cobriria de dignidade. Esta roupa, porém, nada expressa sobre o escravizado, sendo apenas uma "esmola" a alguém que, não tendo o pão ou vestes, tem de seu apenas a morte. Outra obra que oferece uma percepção profunda deste não-ter é o poema "O Navio Negreiro" "14, de autoria de Castro Alves (2016, p. 15), no qual a nudez é convertida em metáfora da dor. Destacamos o seguinte excerto:

\title{
Negras mulheres, suspendendo às tetas magras crianças, cujas bocas pretas rega o sangue das mães outras moças, mas nuas e espantadas no turbilhão de espectros arrastadas em ânsia e mágoa vãs!
}

A maneira como o autor utiliza as palavras é acentuadamente corporal: tetas, bocas e sangue são convertidos em espectros que, na fluidez da travessia do Atlântico, são desterritorializados. Sendo assim, as moças "nuas e espantadas" não têm sobre seus corpos nada que remeta às suas culturas de origem. Em ambos os exemplos, os de Castro Alves (2016) e os de Nabuco (2011), não há tela de representação, sendo os corpos nus comprimidos pelo sistema escravocrata.

Freyre (2004) narra um episódio curioso sobre o roubo de adereços postos sobre uma imagem de São Benedito:

\begin{abstract}
Às vezes guardavam-se joias nas capelas, enfeitando os santos. Daí Nossas Senhoras sobrecarregadas à baiana de tetéias, balangandãs, corações, cavalinhos, cachorrinhos e correntes de ouro. Os ladrões, naquele tempo piedosos, raramente ousavam entrar nas capelas e roubar os santos. É verdade que um roubou o esplendor e outras jóias de São Benedito; mas sob o pretexto, ponderável para a época, de que "negro não devia ter luxo". Com efeito, chegou a proibir-se, nos tempos coloniais, o uso de "ornatos de algum luxo" pelos negros. (FREYRE, 2004, p.40)
\end{abstract}

O inusitado roubo na casa grande revela dois aspectos que servem a esta análise: um deles é a resistência ao culto beneditino, que não era exclusiva dos ladrões da capela mencionados por Freyre (2004), mas que refletia desconfianças do poder eclesiástico ${ }^{15}$. O segundo aspecto, ainda mais útil para a discussão em questão, é a proibição do luxo ao sujeito negro. A indumentária da maruja é significativa porque, em sua opulência, nega a estética austera imposta pelo sistema escravagista. A indumentária subverte a lógica, imposta desde a

\footnotetext{
${ }^{14}$ Expressão do Romantismo brasileiro, o poema foi escrito por Castro Alves em abril de 1868, tendo sido declamado pelo autor no Teatro São José, em São Paulo, no mesmo ano. (BRASIL, 1997).

${ }^{15}$ Sobre esse aspecto, NONATO DA SILVA (2002) escreve que a festividade era acionada "como o principal momento de inversão social e de demonstração de uma fé perene na figura de um santo um tanto marginalizado por parte da hierarquia católica: São Benedito" (p.32).
} 
Antiguidade, pela qual o indivíduo escravizado não teria corpo, personalidade ou ancestralidade $^{16}$.

Por esta outra ótica, é justamente através seu corpo que o indivíduo escravizado expressa a personalidade - pertencimento, crenças, resistências - e sua ancestralidade, ainda que diluída pelos reagrupamentos étnicos que forçaram outras alianças, como analisou Souza (2002). Isto leva, mais uma vez, às telas de representação de Hall (2003) e às tentativas de negação de identidades engendradas pelos poderes constituídos - referidas anteriormente como "telas comprimidas" -, pois nem todos os signos portados pelo corpo são admitidos ou estimulados nas relações sociais. O corpo suporta identidades, porém não o faz impunemente, uma vez que "That body is no ideologically neutral space" (HERZFELD, 2004, p.25). Portanto,

[...] o corpo - sua doença, sua sexualidade, seus prazeres, seus gestos e posturas, sua sensorialidade, sua relação com os objetos, com o espaço e com o outro - é atravessado por instituições, instrumentos, saberes, poderes etc. (BRUNO, 1999, p. 101)

A percepção da dicotomia entre a proibição do luxo ao indivíduo escravizado e a utilização do corpo como veículo de expressão de repertórios culturais africanos auxilia na compreensão das relações operadas pela indumentária na marujada, uma vez que nesta manifestação há "forte relação entre visualidade e identidade, pois é por meio dos signos corporificados na figura da maruja que é possível identificar o seu papel naquele contexto" (SANTOS, 2017).

\section{A INDUMENTÁRIA NA MARUJADA.}

No universo contemporâneo da marujada, que, como já visto, resulta de um contexto escravista, é pertinente mencionar um diálogo transcrito por Brandão da Silva (1997, p.203). O autor relata em seu livro o contato que teve com uma maruja chamada Sibá, obtido em trabalho de campo. Durante este contato, a maruja conta que, mesmo sendo "uma pessoa de idade", um homem mais jovem a "enxergou” e a convidou para dançar. O pesquisador, então, pergunta a ela: "Mas ele a enxergou porque a senhora está vestida de maruja?".

A pergunta diz muito sobre as sociabilidades na marujada. Vestir a indumentária implica em ser maruja e em ser "enxergada" como tal, pois "a indumentária e as pessoas

\footnotetext{
16 Sobre o escravo, escreve Mauss (2015): "Ele não tem personalidade, não possui seu corpo, não tem antepassados, nome, cognomem, bens próprios" (p.387).
} 
constituem reciprocamente um o outro" (MILLER, 2013, p.120). De fato, Fernandes (2011) percebe que, para o turista, indumentária e marujada são uma coisa só. De fato, exceto durante a procissão - na qual o andor de São Benedito, estandartes e bandeiras também compõem a visualidade do evento - durante os demais ritos, tais como a dança, é através dos marujos e marujas que o espectador percebe a manifestação.

Brandão da Silva (1997, p.204) aponta que, na marujada, a indumentária representa uma concorrência simbólica que atesta o sacrifício para o pagamento da promessa, e que assim "todos procuram caprichar no acabamento de suas indumentárias". A importância deste "capricho", de acordo com o autor, residiria no fato que a maruja tem "um sentido de identidade alicerçado na noção de milagre" (BRANDÃO DA SILVA, 1997, p.266). Diante dos obstáculos em obter todos os itens necessários à indumentária, vestir-se como maruja significaria corporificar a devoção, agradecer e demonstrar um sacrifício que reafirma o vínculo entre a pessoa e a santidade:

As dificuldades encontradas são as mais variadas. A confecção do chapéu, a compra dos tecidos para a preparação do uniforme, a compra de um ou outro enfeite, a aquisição de novas fitas, enfim, se preparar a contento é uma prova do seu sacrifício, da dedicação de sua fé e uma maneira de reforçar o caráter miraculoso da Santidade. (BRANDÃO DA SILVA, 1997, p.202)

Esta concorrência simbólica percebida por Brandão da Silva (1997) possui implicações práticas definidas, pois, "na marujada, a indumentária delimita os espaços que os sujeitos podem ou não ocupar" (SANTOS, 2017, p.95). Durante as danças no barracão ou no Teatro Museu da marujada, ser "enxergada" - termo utilizado por Brandão da Silva (1997) como maruja implica em ser, também, avaliada pelas demais marujas e por outros membros da IMSBB. Caso a blusa, a saia ou, principalmente, o chapéu de uma maruja esteja em desacordo com aquilo a que se convencionou chamar "tradição", esta maruja será proibida de permanecer naquele ambiente, tal como pudemos constatar em entrevistas com o sr. João Batista Pinheiro, o Careca - atual presidente da IMSBB - e com marujas pertencentes ao "quadro"17.

A compreensão da indumentária como canal de comunicação - seja este entre um ser humano e outro ser humano, seja entre um ser humano e uma divindade a quem aquele busca honrar por meio daquilo que veste - resulta em um reconhecimento que a indumentária não

\footnotetext{
${ }^{17}$ Marujas "do quadro" são aquelas que não apenas cumprem suas promessas durante a procissão de São Benedito, realizada todos os anos no dia 26 de dezembro, mas as que efetivamente participam da IMSBB e de suas atividades ao longo do ano. Geralmente são marujas mais idosas e conhecedoras do código de vestuário exigido pela instituição.
} 
apenas exprime, mas também compõe identidades. Isto porque

\begin{abstract}
Alguns são rituais puramente verbais, vocalizados, não registrados; desaparecem no ar e dificilmente ajudam a restringir o âmbito da interpretação. Rituais mais eficazes usam coisas materiais, e podemos supor que, quanto mais custosa a pompa ritual, tanto mais forte a intenção de fixar significados (DOUGLAS; ISHERWOOD, 2013, p.110)
\end{abstract}

Neste âmbito, a materialidade representada pela indumentária evoca a complexidade do ritual, visibiliza identidades e religiosidades, revela concepções de mundo e estabelece relações humanas. A eficácia do ritual, por isso, está invariavelmente ligada à sua capacidade de fixar significados naqueles que o assistem e naqueles que dele participam. A indumentária da marujada, na medida em que "reforça o caráter miraculoso da santidade" (BRANDÃO DA SILVA, 1997), tem a intenção de comunicar ao santo o sacrifício na preparação para a celebração e, simultaneamente, comunicar a identidade de uma maruja "verdadeira" 18 frente aos demais.

\title{
6. OUTRO TEMPO.
}

A escravidão africana no Brasil resultou em expressões religiosas que rearticulam e ressignificam repertórios de modo a expressá-los ou de estrategicamente codificá-los, conforme suas necessidades frente ao poder hegemônico. Tais expressões religiosas, portanto, consubstanciam resistências e negociações. A partir desta reflexão, seguimos o pensamento de Hall (2003) que compreende, no contexto da diáspora, que "[...] na cultura popular negra, estritamente falando, em termos etnográficos, não existem formas puras" (HALL, 2003, p.343). Assim, a marujada traz, na materialidade e na estética que lhe são próprias, elementos de culturas africanas, bem como elementos oriundos do catolicismo, estes assimilados conforme as tensões e disputas de poder que ocorreram ao longo da tradição beneditina em Bragança.

Este é o motivo pelo qual "nas vestes, nas suas imagens, cheiros, texturas, podemos reconstituir identidades, ainda que fragmentárias, flexíveis, distantes..." (CIDREIRA, 2013, p. 6). Vestir-se significa colocar-se frente ao outro, ao seu repertório e ao seu julgamento. Na marujada, a materialidade posta sobre o corpo pode evocar leituras de aceitação ou negação, de pertencimento ou status segundo os critérios da tradição constituída. Ainda assim, a transformação ocorre nas vestes e nas personas, pois, "se mirarmos a longo prazo, torna-se

\footnotetext{
${ }^{18}$ Termo utilizado por Aparecida Santos, maruja entrevistada durante trabalho de campo.
} 
ainda mais claro que não só a indumentária está mudando, mas o outro lado da equação, o eu, está mudando também" (MILLER, 2013, p.61).

Quanto a este aspecto, consideramos que a aparente divergência entre a intangibilidade e o mundo material vestível, na marujada, foi bem traduzida por Fernandes quando discorre acerca das "indumentárias e ornamentos que circunscrevem seus usuários em outro tempo, o da tradição" (2011, p.74). De fato, a indumentária da maruja evoca outra temporalidade em Bragança, na qual "ecoam ainda vozes dos pretos velhos que contam as histórias de quilombos e aquilombados da mata, das condições impostas ao negro na sociedade colonial, e de resistências" (CASTRO, 2006, p.11). E o passado, ao mesmo tempo em que dilui as fontes às quais se poderia recorrer, enriquece também a experiência de buscar os repertórios por trás das telas de representação descritas por Hall (2003). Há, decerto, muito a descobrir acerca destas telas.

\section{REFERÊNCIAS}

ALENCAR, Larissa Fontinele de. No Rastro dos Pés Descalços: Da marujada à narrativa literária. Dissertação (Mestrado em Linguagens e Saberes na Amazônia)-UFPA, Bragança, 2014.

BORDALlO DA SILVA, Armando. Contribuição ao Estudo do Folclore Amazônico na Zona Bragantina. Boletim do Museu Paraense Emílio Goeldi, Antropologia nº5, 1959. Disponível em: http://repositorio.museu-goeldi.br/handle/mgoeldi/471. Acesso: 07 de dezembro de 2016.

BRANDÃO, Ascânio. São Benedito: o Santo Preto. Aparecida: Santuário, 1979.

BRANDÃO DA SILVA, Dedival. Os Tambores da Esperança: Um estudo sobre cultura, religião, simbolismo e ritual na festa de São Benedito da cidade de Bragança. São Luís: Falangola, 1997.

BRUNO, Fernanda. Membranas e Interfaces. In: Que Corpo É Esse?. Organização Nízia Vilaça. Rio de Janeiro, Mauad, 1999, p. 98-113.

CÂMARA CASCUDO, Luís da. Dicionário do Folclore Brasileiro. Rio de Janeiro: MEC, 1962.

Rêde de Dormir - Uma pesquisa etnográfica. Rio de Janeiro: MEC, 1959.

CAStro AlveS, A.F. O Navio Negreiro. Coleção Primórdios do Fantástico Brasileiro. Luís Eduardo Magalhães: EX! Editora, 2016.

CASTRO, Edna. Escravos e Senhores de Bragança. Belém: NAEA, 2006.

CIDREIRA, Renata Pitombo. A Dimensão Afetiva da Vestimenta. In: $9^{\circ}$ COLÓQUIO DE 
MODA. 2013, Fortaleza. Anais Disponível em: http://www.coloquiomoda.com.br/anais/9coloquio-de-moda-apresentacao.php. Acesso em: 07 de novembro de 2016.

DOUGLAS, Mary; ISHERWOOD, Baron. O Mundo dos Bens: Para uma antropologia do consumo. Trad. Plínio Dentzien. 2a ed. Rio de Janeiro: Editora da UFRJ, 2013.

FERNANDES, José Guilherme dos S. Pés que Andam, Pés que Dançam: Memória, identidade e região cultural na esmolação e marujada de São Benedito em Bragança (PA). Belém: EDUEPA, 2011.

FERRETTI, Sérgio E. Sincretismo Afro-Brasileiro e Resistência Cultural. Porto Alegre: Horizontes Antropológicos nº 8, 1998.

FREYRE, Gilberto. Casa Grande \& Senzala. 49ª ed. São Paulo: Global Editora, 2004.

HALL, Stuart. Da Diáspora: Identidades e mediações culturais. Trad.: Adelaine La Guardia Resende et al. Liv Sovik (org.). Belo Horizonte: Editora da UFMG, 2003.

HERZFELD, Michael. The Body Impolitic: Artisans and artifice in the global hierarchy of value. Chicago: University of Chicago Press, 2004.

MAUÉS, Raymundo Heraldo. Um Aspecto da Diversidade Cultural do Caboclo Amazônico: a religião. In: Estudos Avançados, 2005, p 259-254.

MAUSS, Marcel. Sociologia e Antropologia Trad. Paulo Neves. $2^{\text {a }}$ ed. São Paulo: CosacNaify, 2015.

MILLER, Daniel. Trecos, Troços e Coisas: Estudos antropológicos sobre a cultura material. Trad.: Renato Aguiar. Rio de Janeiro: Zahar, 2013.

MORAES, Maria José Pinto da Costa; ALIVERTI, Mavilda Jorge; SILVA, Rosa Maria Mota da. Tocando a Memória - Rabeca. Instituto de Artes do Pará. Belém: 2006.

NABUCO, Joaquim. O Abolicionismo. Rio de Janeiro: Centro Edelstein de Pesquisas Sociais, 2011.

NONATO DA SILVA, Dário Benedito Rodrigues. Os Donos de São Benedito: Convenções e rebeldias na luta entre o catolicismo tradicional e devocional na cultura de Bragança, século XX. 2006. Dissertação (Mestrado em História Social da Amazônia)-UFPA, Belém, 2006.

RANGEL, Maria Cristina; GOMBERG, Estélio. A Água no Candomblé: A relação homemnatureza e a geograficidade do espaço mítico. In: XVIII ENCONTRO NACIONAL DE GEÓGRAFOS, São Luís, 2016.

SALLES, Vicente. O Negro na Formação da Sociedade Paraense. $2^{\text {a }}$ ed. Belém: Paka-Tatu, 2015 .

SANTOS, Ana Mabell Seixas Alves. Aves da Marujada: A utilização de penas na confecção do chapéu da maruja. Nova Revista Amazônica, Ano V, Volume 1, Maio 2017, p.81-102. 
SANTOS, Helane Súzia Silva dos. BRITO, Maria dos Remédios de. Bragança e a Marujada: Pedaços de imanência. Linha Mestra, n²8, Jan/Abr 2016.

SKEEHAN, Danielle C. Caribbean Women, Creole Fashioning and the Fabric of Black Atlantic Writing. In: The Eighteenth Century. v.56, nº1, 2015, p.105-123.

SOUZA, Marina de Mello. Catolicismo Negro no Brasil: Santos e minkisi, uma reflexão sobre miscigenação cultural. Afro-Ásia, nº 28, 2002, p.125-146.

VAT, Frei Odulfo van der. São Benedito, o Preto, e Seu Culto no Brasil. Revista Eclesiástica Brasileira, 1941. 